\title{
A Comparative Study on the Quality of Available Brand and Non Brand Fluid Milk Consumed by the People of Chittagong City of Bangladesh
}

\author{
Debnath GK ${ }^{1}$, Kober AKMH ${ }^{1 *}$, Chanda ${ }^{2}{ }^{2}$, Chanda GC ${ }^{1}$ and Bari MS \\ 'Dept. of Dairy and Poultry Science, Chittagong Veterinary and Animal Sciences University, Chittagong, \\ Bangladesh; ${ }^{2}$ Dept. of Dairy and Poultry Science, Patuakhali Science \& Technology University, Patuakhali, \\ Bangladesh.
}

[Received: April 21, Accepted: May 19, 2014]

\begin{abstract}
The study was undertaken to have a comparative investigation on the quality of available brand and non-brand fluid milk consumed by the inhabitants of Chittagong City (CC). Milk samples were collected from the city vendors, departmental stores, households and dairy farms. A total of 100 samples were analyzed for nutritional (percentage of butter fat, solids-not-fat and protein), chemical (pasteurization test, added preservatives and adulteration status) and microbial (standard plate count and coliform count) parameters to evaluate the quality of the collected milk samples. The study reveals that the collected milk samples show significant $(\mathrm{P}<0.01)$ variation in nutritional, chemical and microbiological parameters among the sources. All brands milk samples were properly pasteurized. The quality of milk samples from local farms was good except coliform counts. All the samples possessed high coliform counts. The quality of farm produced milk and rural milk were deteriorated by middlemen due to adulteration with water. Water adulteration was detected in $68 \%$ and $54 \%$ of the milk samples in case of vendor supplied rural and vendor supplied farm milk respectively. Most alarming fact is more than $10 \%$ milk samples contained formalin in case of vendor supplied rural milk. It may be concluded that both the vendor supplied rural milk and vendor supplied farm milk were low quality due to water adulteration and added formalin preservatives respectively.
\end{abstract}

Keywords: Adulteration, brand milk, chemical, non-brand milk, quality.

\section{INTRODUCTION}

Milk has been the quality food sources for humans since long before the recorded history. It is wellknown that milk is "almost complete" as well as wholesome nutritious food for all mammals including human being. Chittagong is the second largest city called as port city and commercial capital of Bangladesh. Human population of Chittagong city (CC) is 2,592,439 ${ }^{[1]}$ and total estimated demand ( $250 \mathrm{ml} /$ day/person) of fluid milk is 648110 litre /day. The amount of produced milk in CC is very negligible against the demand. To meet the demand of fluid milk of such a huge population four sources of milk is available in CC namely farm produced milk (FPM), vendor supplied farm milk (VSFM), vendor supplied rural milk (VSRM) and market milk (MM) of different brands. In both farm and village conditions good quality milk can be expected from good management practices of dairy cows. An irregularity and bad management may cause the deterioration in quality of milk produced ${ }^{[2]}$. On the other hand, if milk is adulterated its nutritive value is greatly affected. The study of ${ }^{[3]}$ that was conducted on the quality of milk supplied by different vendors in Mymensingh town, Bangladesh and found that the quality of milk available in the local market were inferior to milk produced at Bangladesh Agricultural University dairy farm, Mymensingh. This result indicates that the consumers are not getting good quality milk from local markets in that area. In order to prevent this, it needs to create awareness among the consumers about the quality of what they are consuming. A large quantity of imported powder milk has been being used along with the fluid milk due to shortage of fluid milk. High quality milk and milk products are necessarily of consumers' demand for which milk production and distribution of quality milk is of utmost importance from the view point of public health. Milk is an excellent food not only for humans but same is true for bacteria also ${ }^{[4]}$. The unprocessed and un-chilled raw milk has very short shelf life and usually gets sour within a few hours due to bacterial growth ${ }^{[5]}$. Clean milk production, handling and transport are thus very important. While it is essential that animal, particularly its udder and teats are cleaned before milking and milkman washes its own hands, cleaning of utensils used in milking, storage and transport are of utmost importance in clean milk production and supply. Various utensils are used for the purpose but buckets and cans are more commonly used ${ }^{[6] .}$ Thus milk and the dairy products can be the important sources of food-borne pathogens. Moreover, adulteration of milk with water, which is very common in Bangladesh, not only causes dilution of milk reducing the milk solids, but also involves the risk of introducing germs into the milk along with further decrease in quality. To keep a surveillance of milk quality especially from government level is necessary like other countries. It needs to have continuous follow up by a team or by a specific department. Though Government of our country possesses Bangladesh Standard and Testing Institute 
(BSTI) under the Ministry of Science and Technology to play this role but surveillance is almost unperceivable. Information is not available on the quality of milk from different sources in CC. However, very limited number of research works has been carried out in Bangladesh regarding milk quality. Therefore, the present study was undertaken with the aim to make a comparative study regarding nutritional, chemical and microbiological quality of the milk from different sources in $\mathrm{CC}$.

\section{MATERIALS AND METHODS}

The milk quality tests were done in the Dairy Science Laboratory under the Dept. of Dairy and Poultry Science of Chittagong Veterinary and Animal Sciences University during the period from $1^{\text {st }}$ August 2007 to $15^{\text {th }}$ February'2008. Before collecting the samples, a survey was conducted and 100 families were randomly selected at Khulshi and

\section{Collection of Sample}

A total of 12 Farm Producing Milk (FPM), 24 Vendors Supplied Farm Milk (VSFM), 19 Vendors Supplied Rural Milk (VSRM) and 45 Market Milk (MM) (9 samples each of five brands) samples were collected from different departmental stores, dairy farms, households and bulk sources of vendors.

\section{Procedure of Sampling}

The FPM samples were collected from farms after milking all the cows and properly mixing with the help of plunger and dipper. The VSFM and VSRM samples were collected from households and bulk sources of vendors with the help of plunger and dipper. The MM samples of five brands were collected from different departmental stores of CC on the basis of date and batch of production.

\section{Quality Tests}

Specific gravity, total solids \%, solids-not-fat (SNF)

Table 1: Nutritional and microbial quality of four types of milk

\begin{tabular}{|c|c|c|c|c|c|c|}
\hline $\begin{array}{l}\text { Source } \\
\text { of } \\
\text { milk }\end{array}$ & $\begin{array}{c}\text { Specific } \\
\text { gravity } \\
(\text { Mean } \pm \text { SE) }\end{array}$ & $\begin{array}{c}\text { BF\% } \\
(\mathrm{Mean} \pm \mathrm{SE})\end{array}$ & $\begin{array}{c}\text { SNF\% } \\
(\text { Mean } \pm \text { SE) }\end{array}$ & $\begin{array}{c}\text { Protein\% } \\
(\text { Mean } \pm \text { SE) }\end{array}$ & $\begin{array}{c}\mathrm{SPC}(\mathrm{CFU} / \mathrm{ml} \\
(\mathrm{Mean} \pm \mathrm{SE})\end{array}$ & $\begin{array}{c}\text { Coliform } \\
(\mathrm{CFU} / \mathrm{ml}) \\
(\mathrm{Mean} \pm \mathrm{SE})\end{array}$ \\
\hline FPM & $1.028^{\mathrm{c}} \pm 0.00$ & $3.75^{\mathrm{c}} \pm 0.04$ & $8.33^{\mathrm{d}} \pm 0.01$ & $3.13^{\mathrm{c}} \pm 0.01$ & $263000^{b} \pm 33$ & $105^{b} \pm 1.10$ \\
\hline VSFM & $1.026^{\mathrm{b}} \pm 0.00$ & $3.52^{\mathrm{b}} \pm 0.02$ & $7.98^{\mathrm{b}} \pm 0.02$ & $2.68^{\mathrm{b}} \pm 0.02$ & $374000^{c} \pm 48$ & $120^{c} \pm 1.26$ \\
\hline VSRM & $1.025^{\mathrm{a}} \pm 0.00$ & $4.01^{\mathrm{d}} \pm 0.03$ & $7.85^{\mathrm{a}} \pm 0.02$ & $2.50^{\mathrm{a}} \pm 0.02$ & $514000^{\mathrm{d}} \pm 23$ & $130^{\mathrm{d}} \pm 1.69$ \\
\hline MM & $1.028^{\mathrm{c}} \pm 0.00$ & $3.40^{\mathrm{a}} \pm 0.02$ & $8.20^{c} \pm 0.01$ & $3.37^{\mathrm{d}} \pm 0.01$ & $2600^{\mathrm{a}} \pm 50$ & Nil \\
\hline $\begin{array}{l}\text { Level of } \\
\text { Sig. }\end{array}$ & $* *$ & $* *$ & $* *$ & $* *$ & $* *$ & $* *$ \\
\hline
\end{tabular}

Table 2: Nutritional, Chemical and Microbial quality of Market Milk of different brands available in Chittagong city

\begin{tabular}{ccccccc}
\hline $\begin{array}{c}\text { Name } \\
\text { of } \\
\text { brands }\end{array}$ & $\begin{array}{c}\text { BF\% } \\
(\text { Mean } \pm \text { SE) }\end{array}$ & $\begin{array}{c}\text { SNF\% } \\
(\text { Mean } \pm \text { SE) }\end{array}$ & $\begin{array}{c}\text { Protein\% } \\
(\text { Mean } \pm \text { SE })\end{array}$ & $\begin{array}{c}\text { Phosphatase } \\
\text { test }\end{array}$ & $\begin{array}{c}\text { SPC } \\
(\mathrm{CFU} / \mathrm{ml}) \\
(\mathrm{Mean} \pm \mathrm{SE})\end{array}$ & $\begin{array}{c}\text { Coliform } \\
(\mathrm{CFU} / \mathrm{ml}) \\
(\mathrm{Mean} \pm \mathrm{SE})\end{array}$ \\
\hline Brand 1 & $3.50^{\mathrm{b}} \pm 0.03$ & $8.20^{\mathrm{ab}} \pm 0.02$ & $3.46^{\mathrm{b}} \pm 0.01$ & $-\mathrm{ve}$ & $2300^{\mathrm{b}} \pm 60$ & Nil \\
Brand 2 & $3.50^{\mathrm{b}} \pm 0.03$ & $\begin{array}{c}8.21^{\mathrm{ab}} \\
\pm 0.02\end{array}$ & $3.36^{\mathrm{a}} \pm 0.02$ & $-\mathrm{ve}$ & $2100^{\mathrm{a}} \pm 52$ & Nil \\
Brand 3 & $3.40^{\mathrm{ab}} \pm 0.05$ & $8.16^{\mathrm{a}} \pm 0.03$ & $3.31^{\mathrm{a}} \pm 0.02$ & $-\mathrm{ve}$ & $2300^{\mathrm{b}} \pm 50$ & Nil \\
Brand 4 & $3.30^{\mathrm{a}} \pm 0.05$ & $8.26^{\mathrm{b}} \pm 0.02$ & $3.35^{\mathrm{a}} \pm 0.03$ & $-\mathrm{ve}$ & $3000^{\mathrm{c}} \pm 76$ & Nil \\
Brand 5 & $3.30^{\mathrm{a}} \pm 0.04$ & $8.17^{\mathrm{a}} \pm 0.02$ & $3.38^{\mathrm{a}} \pm 0.01$ & $-\mathrm{ve}$ & $3300^{\mathrm{d}} \pm 76$ & Nil \\
Level of & $* *$ & $*$ & $* *$ & - & $* *$ & - \\
Sig. & & & & & & \\
\hline
\end{tabular}

Means with different superscript(s) in the same column differ significantly.

*Significant at the 0.05 level, ** Significant at the 0.01 level, $\mathrm{CC}=$ Chittagong City.

Jalalabad areas of CC. Among the 100 families 12, 24, 19 and 45 consumed farm produced milk, vendor supplied farm milk, vendor supplied rural milk and brand milk (Brand 1, Brand 2, Brand 3, Brand 4 and Brand 5) respectively.
$\%$, butter fat $\%$ were determined by ${ }^{[7]}$. The protein percentage was determined by following the method of ${ }^{[8]}$. The Phosphatase test was done by using Gerber Phosphatase Kits. Added preservative (formalin, hydrogen per oxide, borax and bicarbonate) and 
adulterants (added water, cane sugar, starch, skim milk powder) detection tests were performed as per
In spite of water adulteration, the butter fat (BF) content was higher in case of VSRM compared to

Table 3: Status of added preservatives in all four sources of milk available in Chittagong city

\begin{tabular}{|c|c|c|c|c|c|c|c|c|}
\hline \multirow{3}{*}{$\begin{array}{l}\text { Source of } \\
\text { milk }\end{array}$} & \multicolumn{8}{|c|}{ Type of added preservatives } \\
\hline & \multicolumn{2}{|c|}{ Formalin } & \multicolumn{2}{|c|}{$\begin{array}{l}\text { Hydrogen per } \\
\text { oxide }\end{array}$} & \multicolumn{2}{|c|}{ Borax } & \multicolumn{2}{|c|}{ Bicarbonate } \\
\hline & $-\mathrm{Ve} \%$ & $+\mathrm{Ve} \%$ & $-\mathrm{Ve} \%$ & $+\mathrm{Ve} \%$ & $-\mathrm{Ve} \%$ & $+\mathrm{Ve} \%$ & $-\mathrm{Ve} \%$ & $+\mathrm{Ve} \%$ \\
\hline FPM & 100 & 00 & 100 & 00 & 100 & 00 & 100 & 00 \\
\hline VSFM & 100 & 00 & 100 & 00 & 100 & 00 & 100 & 00 \\
\hline VSRM & 89.48 & 10.52 & 100 & 00 & 100 & 00 & 100 & 00 \\
\hline MM & 100 & 00 & ND & ND & 100 & 00 & 100 & 00 \\
\hline
\end{tabular}

FPM =Farm Producing Milk, VSFM=Vendors Supplied Farm Milk, VSRM =Vendors Supplied Rural Milk, MM= Market Milk, CC = Chittagong City

the instruction of ${ }^{[9]}$. Total viable bacterial population and coliform count were done as per recommendation of ${ }^{[10]}$.

\section{Statistical Analysis}

The data were recorded and categorized in Microsoft Office Excel sheet and finally analyzed by Compare means One-way ANOVA by using statistical software SPSS 11.5 version.

\section{RESULTS AND DISCUSSION}

\section{Non brand and Brand Milk}

Among the four sources of milk the average specific gravity was lowest in case of VSRM (1.025), highest in case of FPM (1.028) as shown in Table 1. The lower specific gravity value of VSRM indicates more other three sources (Table 1). It might be due to the reason that milk was collected from indigenous cows and / or mixing of previous day's evening milk to the next day's morning milk since milk from indigenous cattle and evening milk contain higher percentage of fat. The FPM contained $3.75 \% \mathrm{BF}$ which is higher than the findings of ${ }^{[9]}$ for raw milk, the BF content of FPM is satisfactory but quality deterioration was done by vendors. The SNF content of FPM, VSFM, VSRM and MM were 8.33, 7.98, 7.85 and $8.20 \%$, respectively. The SNF content of FPM was slightly higher than the findings of ${ }^{[11]}$ in case of raw farm milk. The SNF content of MM was higher than ${ }^{[1]}$ in case of pasteurized milk. The highest SNF content was estimated in FPM and lowest in VSRM. The protein content of FPM, VSFPM, VSRM and MM were $3.13,2.68,2.50$, and $3.37 \%$, respectively (Table

Table 4: Status of adulteration in all four sources of milk in Chittagong city

\begin{tabular}{|c|c|c|c|c|c|c|c|c|}
\hline \multirow{3}{*}{$\begin{array}{l}\text { Sources of } \\
\text { milk }\end{array}$} & \multicolumn{8}{|c|}{ Type of adulterants used } \\
\hline & \multicolumn{2}{|c|}{ Water } & \multicolumn{2}{|c|}{ Cane sugar } & \multicolumn{2}{|c|}{ Starch } & \multicolumn{2}{|c|}{ Powder milk } \\
\hline & $-\mathrm{Ve} \%$ & $+\mathrm{Ve} \%$ & $-\mathrm{Ve} \%$ & $+\mathrm{Ve} \%$ & $-\mathrm{Ve} \%$ & $+\mathrm{Ve} \%$ & $-\mathrm{Ve} \%$ & $+\mathrm{Ve} \%$ \\
\hline FPM & 100 & 00 & 100 & 00 & 100 & 00 & 100 & 00 \\
\hline VSFM & 45.83 & 54.17 & 100 & 00 & 100 & 00 & 100 & 00 \\
\hline VSRM & 31.56 & 68.24 & 100 & 00 & 100 & 00 & 100 & 00 \\
\hline MM & 100 & 00 & 100 & 00 & 100 & 00 & ND & ND \\
\hline
\end{tabular}

FPM =Farm Producing Milk, VSFM=Vendors Supplied Farm Milk, VSRM =Vendors Supplied Rural Milk, MM= Market Milk, CC = Chittagong City

water adulteration. The nutritional quality of FPM and rural milk was deteriorated by middlemen due to water adulteration. This result is agreed with the findings of ${ }^{[3]}$. The average specific gravity of $\mathrm{MM}$ was within the limit (1.028-1.032) of Bangladesh Standard ${ }^{[1]}$. The average specific gravity of VSRM was slightly lower than the standard value of raw milk (1.026-1.034). But the average specific gravity of other non- brand milk samples were within the range.
1). The highest protein was found in MM and lowest in VSRM. The protein content of raw milk was recorded $3.77 \%{ }^{[12]}$, which greatly differed from the present findings. It might be due to the inadequate protein content in ration. The protein content of MM was 3.37 which agreed with the protein content of ${ }^{[1]}$ standard for pasteurized milk. The less protein content in VSRM might be due to adulteration with water. The SPC of the raw milk was within the limit of standard but greatly differed from the MM. The 
SPC of the MM was greatly lower than the findings of ${ }^{[1]}$. The coliform count was higher in case of FPM, VSFM, and VSRM than the standard value but lower in case of MM. The higher counts of coliform in case of FPM, VSFPM and VSRM indicate that proper hygienic measures were not taken before and during milking. The coliform count of raw milk agreed with the findings of ${ }^{[13]}$. The statistical analysis showed that the specific gravity, BF, SNF, protein, SPC and coliform count differed significantly $(\mathrm{P}<0.01)$ among the sources.

\section{Brand Milk}

Table 2 shows that the MM of all five brands available in CC was properly pasteurized and bacterial count very satisfactory and also shows that all brands of MM contained a bit higher amount of $\mathrm{SNF}$ and protein though the average BF percentage was a bit lower than the ${ }^{[1]}$ except Brand 1 and Brand 2 but well acceptable. The quality of Brand 1 sample was the best in every aspect among all brands of MM available in Chittagong city (Table 2). The statistical analysis showed that the difference in the mean of BF, protein and SPC were highly significant $(\mathrm{P}<0.01)$ and the mean of $\mathrm{SNF}$ also differed significantly $(\mathrm{P}<0.05)$ among the various brands of milk.

\section{Added preservatives quality}

Table 3 shows that $10.52 \%$ of VSRM samples contained added formalin which is dangerous for human health and other three sources of milk free from any type of added preservative. Formalin causes vomiting, diarrhea and abdominal pain in human. The present findings of the study were agreed with the findings of ${ }^{[14]}$ in case of adding formalin as preservatives by middleman supplied rural milk.

\section{Adulteration in Milk}

Water adulteration was found in case of VSFM and VSRM but FPM and MM were free from added water (Table 4). Water adulteration was detected in $68.24 \%$ and $54.17 \%$ of samples in case of VSRM and VSFM respectively. The present findings were higher than the findings of ${ }^{[15]}$. Standardization is the common steps for market milk processing and it is done either by adding skim milk or powder milk. So, adulteration of powder milk test was not performed in case of MM.

\section{CONCLUSION}

Results of this study showed that nutritional and chemical quality of FPM and MM of all five brands were satisfactory but vendors supplied milk was below standard due to water adulteration. Microbial quality of MM of all five brands was very safe for human consumption. High fat content even watering and presence of formalin in some samples of VSRM indicates evening milk of previous day mixing with morning milk of next day. Further study needed regarding the chemical (adulteration) and microbiological quality for all sources of milk. City Corporation authority and BSTI should come forward to ensure safe milk for city people of Chittagong with the help of Dept. Dairy Science, CVASU.

\section{REFERENCES}

1. Bangladesh Standard (BDS) (2002). Specification for Pasteurized milk. Bangladesh Standards and Testing Institution, Dhaka.

2. Islam MN, Ali MS, Kober AKMH' Amin MR (2002). Quality of milk consumed by resident people Bangladesh Agricultural University Campus, Mymensingh. Bangla. Vet. 19:29-33.

3. Islam MN, Husain SMI, Mannan AKM (1984). Studies on the physical parameters and chemical quality on market milk in Mymensingh town (Bangladesh). Bangla. J. Anim. Sci. 13:52-54.

4. Chanda T, Debnath GK, Hossain ME, Islam MA, Begum MK (2012). Adulteration raw milk in the rural areas of Barisal district of Bangladesh. Bangla. J. Anim. Sci. 41(2):112115.

5. http://www.ilri.org/InfoServ/Webpub/fulldocs /ilca_manual4/Microbiology.htm

6. Afzal M (2010). Re-designing smallholder dairy production in Pakistan. Pak. Vet. J. 30:187-190.

7. Food and Agriculture Organization (FAO) of the United Nations (1984). A Manual on milk and milk products testing procedures. Cooperative Dairy Organization and Extension Programme (Phase II), Bangladesh, 24-25, 1819, 22-23 pp.

8. Payne, GT (1932). The determination of milkproteins by formaldehyde titration. Biochem. J. 26:1006-1014.

9. Directorate General of Health Service (DGHS) (2005). Manual of methods of analysis of foods (milk and milk products). Ministry of health and family welfare, India, $1,3,15,17,18$ pp.

10. American Public Health Association (APHA) (1967). Standard Methods for the Examination of Dairy Products. American Public Health Association. Inc. $12^{\text {th }}$ edn. New York, $90-110$ pp.

11. Graf TF (1976). Market implications of changing fat content of milk and dairy products, fat content and composition of animal products: Proceedings of a symposium, board on agriculture and renewable resources, commission on natural resources. Food and Nutrition Board, Assembly of Life Sciences, National Research Council, National Academy of Sciences, 189190 pp.

12. Lingathurai $S$, Vellathurai $P$, Vendan SE, Anand AAP (2009). A comparative study on 
the microbiological and chemical composition of cow milk from different locations in Madurai, Tamil Nadu. Indian J. Sci. Tech. 2:51-54.

13. Sraïri MT, Moudnib J, Rahho L, Hamama, A (2006). How do milking conditions affect the hygienic quality of raw milk? Case study from Moroccan dairy farms. Livestock Research for Rural Development. Hassan II Agronomy and Veterinary Medicine Institute, 18:97.
14. Tariq MA (2001). Subject: A close look at dietary patterns. http://www. dawn.com/2001/11/05/ebr13.htm. Accessed on Feb, 2011.

15. Ahmad A (2009). Milk adulteration by adding water and starch at Khartoum state. Pak. J. Nutri. 8:439-440. 